Volume XII, No. 2, pp 100-108, 2011

\title{
WHAT TO TEACH IN THE INTRODUCTORY CIS COURSE?
}

\author{
Jeanne M Baugh, Robert Morris University,baugh@rmu.edu \\ Paul J. Kovacs, Robert Morris University,kovacs@rmu.edu
}

\begin{abstract}
In many institutions of higher education, students are required to take an Introduction to Computer Information Systems course. The course is often also the first course required to be taken by a student majoring in Computer Information Systems. It can cover everything from Information Systems concepts to applications such as Excel and Access. Furthermore, the course can be taught in many different manners. A body of knowledge for this course has been defined by the IS2010 Model Curriculum, but for many reasons, it may not be possible to cover all suggested topics. This paper addressed what is currently being done in various institutions for such an introductory course. The discussion centers on the idea that the course can contain different topics depending upon how it is used in the Institution's specific curriculum.
\end{abstract}

\section{Keywords: Computer literacy, Computer Information Systems Coursework, CIS Curricula, Introductory CIS Course}

\section{INTRODUCTION}

What is a computer literacy course? What should be taught and how should it be taught? Is it taught differently if it is a core course versus a required course in the CIS curriculum?

"Acquiring computer skills is more important today than ever before. Teaching of computer skills, however, has to adapt to new technology." [15]. Because technology areas are being increasingly used by organizations to support their work, students will need these skills to compete in the job market. Previous analysis states that literacy skills of the students span three areas, entertainment, communication, and construction. Further, "each is important to consider, in that high levels of use across categories indicate a broad base of technology skills" [3].

The required course in a core curriculum is often referred to as a computer literacy course. The term "computer literacy" means different things to different people [12]. The IS2010 model curriculum attempts to

address what should be taught in such a course [8]. In that model curriculum, the course, IS 2010.1

Foundations of Information Systems is defined as a course that all students should take, not just the Information Systems major. Should the course be application software such as excel and access? Or, should it be Information Systems concepts? Or should it be both? [2] What do the non-CIS (Computer and Information Systems) majors need to know to be competent?

The IS2010, Model Curriculum summarizes the beginning course, 2010.1 as follows:

"Information systems are an integral part of all business activities and careers. This course is designed to introduce students to contemporary information systems and demonstrate how these systems are used throughout global organizations. The focus of this course will be on the key components of information systems - people, software, hardware, data, and communication technologies, and how these components can be integrated and managed to create competitive advantage. Through the knowledge of how IS provides a competitive advantage students will gain an understanding of how information is used in organizations and how IT enables improvement in quality, speed, and agility. This course also provides an introduction to systems and development concepts, technology acquisition, and various types of application software that have become prevalent or are emerging in modern organizations and society.” 
Volume XII, No. 2, pp 100-108, 2011

And, the suggested topics for this beginning course are:

1. Characteristics of the Digital World

2. Information systems components

- Hardware

- Software

- Data

- Networks

- Facilities

- Personnel

- Services

- Partners

3. Information systems in organizations

- Characteristics of IS professionals

- IS career paths

- Cost/value information

- Quality of information

- Competitive advantage of information

- IS and organizational strategy

- Value chains and networks

4. Globalization

- What is globalization?

- Technology enabled change

- Digital divide

- Cultural, ethnic, political challenges

- Global information systems strategies

5. Valuing information systems

- How information systems enable organizational processes

- Making a business case for information systems

- Productivity paradox of information systems

- Investment evaluation

a. Multi-criteria analysis

b. Cost-benefit analysis

- Identifying and implementing innovations

6. Information systems infrastructure

- Hardware

- Software

- Collaboration and communication technologies

- Data and knowledge

- Faculties

- Services

- Personnel

- Partnerships

7. The Internet and WWW

- E-business
a. B-to-C
b. B-to-B

- Intranets, Internet, extranets

- E-government

- Web 2.0 
a. Technologies:e.g., wikis, tags, blogs, netcasts, self-publishing

b. New forms of collaboration: social networking, virtual teams, viral marketing, crowdsourcing

8. Security of information systems

- Threats to information systems

- Technology-based safeguards

- Human-based safeguards

- Information systems security planning and management

9. Business intelligence

- Organizational decision making, functions, and levels

a. Executive, managerial, and operational levels

b. Systems to support organizational functions and decision making

- Information and knowledge discovery

a. Reporting systems

b. Online analytical processing

c. Data, text, and Web mining

d. Business analytics

- Application systems

a. Executive, managerial, and operational support systems

b. Decision support systems

c. Functional area information systems

d. Collaboration technologies

e. Intelligent systems

f. Knowledge management systems

- Information visualization

a. Visual analytics

b. Dashboards

c. Geographic information systems

10. Enterprise-wide information systems

- Enterprise resource planning

- Supply chain management

- Customer relationship management

11. Development and acquisition

- Systems development lifecycle

- Alternative development approaches

- External acquisition

- Outsourcing

- End-user development

12. Information systems ethics and crime

- Information privacy, accuracy, property, and accessibility

- Computer crime

- Cyberwar / cyberterrorism

These learning objectives range from understanding how and why information systems are used, to ethical concerns that information systems raise in society. This list is extremely large and often not possible to cover in only one semester course.

The topics to be covered in such a course have been and are still open to debate. [16] What students should have mastered after completing a literacy course will be as different as the many institutions that teach such a course.

One must also consider that this introductory course is being taught to both CIS and non-CIS majors. But one thing seems certain; this is a course that all students need [10]. 
For those who have taught this course, it is clear that covering all of this information is sometimes not possible. When you have fifteen weeks in a semester it is tough, but what about the condensed eight week terms? To make it even more difficult, teach the course in eight weeks and online!

Sixteen institutions of higher education in the Southwestern Pennsylvania (Pittsburgh) area were reviewed to assess what is being taught in their own version of this introductory course. The course descriptions of these institutions, as reported online, were searched and a chart showing the major topics taught at each institution is contained in figure \#1 of the Appendix. The major topics tracked were, Spreadsheet, Database, Web, IS Concepts, Business Concepts, Networking and Programming. A summary of these topics taught can be seen in figure \#2 of the Appendix.

It is clear that almost all of the institutions indicate that this Introductory CIS course covers the areas of Spreadsheets, Databases, Web, and CIS concepts. Only three were covering programming in this course. What is important to note is that all have a business emphasis. That "business" emphasis can be business of education, nursing, accounting, communications, engineering etc...

The author's institution's course description is a follows:

Provides the student with an understanding of how decision support systems using the capabilities of the computer can be combined with human intelligence to make better decisions. The course focuses on how information is collected, stored, organized, and managed to assist persons at all organizational levels make more effective decisions. Problem solving and decision-making are examined within the framework of information systems that use databases and spreadsheets as tools that assist with the processes. Specifically, students use Microsoft Excel to address such topics as "what-if" scenarios, sensitivity analysis, plotting and graphic displays. Microsoft Access is also used to gain experience in designing and creating effective databases, developing effective data interfaces, creating queries, and generating meaningful business reports.

"Information Systems Applications provides the student with an integrated perspective of technology and information systems used to support the operation of an organization. The course involves both an overview of technological concepts and practice using application software to enhance decision-making. Concepts addressed include: computer hardware and software, telecommunications and networks, the Internet and intranets, data management, and decision support systems. The student learns to support decision-making necessary to the modern workplace by completing a series of individual and group projects. The projects include case studies requiring the use of spreadsheet and database management software."

This description indicates that many of the major areas of the IS2010, Model Curriculum are covered. [8]. It must also be noted that the CIS concepts are also expected to be covered.

Some have taught the course using the student's major as the focus of all assignments. This method has shown some success [2]. The content and delivery method of the course should be examined often in order to stay current with changing technology as well as teaching pedagogy. [6]

A few questions arise when looking at the daunting list of course topics:

What topics are reasonable to cover?

How can the selected topics be covered?

\section{SELECT TOPICS}

This is an important course and as such, all topics are important. But there is only a finite amount of time in the semester. It is clear to all of us who have taught this course at the author's institution, that there simply is not 
enough time to cover everything and some topics will have to be eliminated. But which of these topics should not be covered? There is no one-size-fits-all solution for this problem.

If the students in the course are all CIS majors, then the decision of which topics to keep and which ones to skip is somewhat easier. The Instructors in the CIS department should be able come to an agreement on what their major should know at the completion of the course. But the student mix is not always homogeneous in terms of the student's major.

The instructors of the CIS department must provide input as to what needs to be taught. A survey could be presented having the questions aligned with the topics as defined in the IS2010 Curriculum. The instructors would be asked to assign weights to the various topics, both for the CIS major taking the course and the non-CIS-major. How much in depth should the spreadsheet portion of the course go? With the database section, perhaps it is enough to have the non-CIS students learn to "use" a database and not have to "create" one? An in-depth survey of the instructors would answer these application topic issues as well as defining necessary CIS concept topics. Getting all in the CIS department to agree on topics their students should know may not be as easy as one might think. Because many instructors have specific interests, they may tend to want their topics included in the course. However, we all know this is not possible.

Another consideration that must not be overlooked is that other departments on campus expect their students to come out of this course with a master of certain computer skills. For example, the Business Department in the Author's institution expects the students to be very proficient with Spreadsheet software (Excel). The Nursing Department expects their students to come out of this course having knowledge of Medical Information Systems.

If this course is one in the University core, and other departments depend on a certain proficiency at the completion of the course, then the course must address their needs. The danger of presenting the course in a vacuum is that the other departments could opt to create a course of their own.

The various departments should periodically be surveyed to see if the course is aligned with their needs. It must be noted that the course may not do everything that every department may want. But, by keeping the other elements of the University in the loop, the possibility that the course could leave the CIS Department is minimized.

A survey will be administered over the summer to all departments in the Author's Institution. Some of the questions that will be presented to the various department heads are as follows:

- What Excel tasks do your expect your students to master?

- How important is it to you that your students create a database?

- How important is to you that your students are able to use a database?

- How important is it to you that your students are able to create a simple web page?

- How important is it to you that your students have knowledge of collaboration techniques using various technologies?

- Do you want your students to have any exposure to major specific software? If so, what software?

- How important is it to you that your students understand hardware components?

- How important is it to you that your students understand security issues concerning computer information systems?

- How important is it to you that your students understand Web topics such as wikis, tags, and blogs?

- How important is it to you that your students understand the various aspects of social networking (including various security concerns)?

- How important is it to you that your students understand the role of information systems in the decision making process of various organizations? 
Volume XII, No. 2, pp 100-108, 2011

\section{STRUCTURE COURSE}

Computer literacy must encompass an understanding of business and enterprise needs. [14] To do that, the individual instructor has the freedom to present the material to the students using various pedagogies. Each Instructor has his own methods of teaching and the academic freedom enjoyed in the class room is something that is not taken lightly. [7]

Lecture, lab, student presentations, student web and software projects...these are all possible approaches.

It is imperative that the proper textbook and learning materials be selected and used. This textbook or series of textbooks should be designed for the lecture/lab approach as well as for the tutorial/hands-on approach. The textbook should contain two major features. First, the textbook should be task-driven and contains realistic projects that solve a complete business problem. By working through realistic projects, students learn not only the mechanics of the software, but are introduced to situations that they may encounter in other business classes as well as the workplace. Second, the content, organization, and pedagogy of the textbook should make full use of the graphical user interface environment. The textbook should provide step-by-step instructions of each of the tasks required to complete a given project. Additionally, the textbook should show the actual screens displayed by the graphical user interface and the application software.

The course is designed to emphasize meaningful receptive and discovery learning as opposed to rote receptive learning. Meaningful receptive learning implies that new material is presented to the student and the student relates it to existing knowledge. Meaningful discovery learning has the student arrive at the solution to a problem on his/her own. With rote receptive learning, the material is presented in final form and is committed to memory. [1] The lecture/textbook approach is employed to assure meaningful receptive learning. The professor spends time lecturing on the concepts and the material in the textbook. The student is required to study the material and then to apply the knowledge to a business application on the microcomputer. A tutorial/hands-on approach could also be used to assure meaningful discovery learning. The student could independently perform each task within an assignment following step by step instructions. In this way the student would encounter errors and problems and discovers answers to them.

A more unconventional approach could also be used. The students could be given assignments that apply a specific concept to a real world problem of interest to the student. Past research "indicates the need for computer literacy appropriate to the employment situation.” [13]

The student could choose a business or organization that he would model for the semester. This could be a fictitious business or organization or it might be a real one in which the student may or may not have been involved. The business/organization would need to meet the following requirements:

- It has employees

- It offers a service or produces a product

- It has a variety of financial needs

Then all of the assignments could be related to that organization. For example:

- Create a payroll spreadsheet

- Create an employee database

- Design a network system for the organization

- Create a simple web site

- Select specific application software for the organization

Relate the topics to the student's interests, or their major's subject areas. Many CIS topics can be presented in this manner if the instructor is willing to be creative and innovative. [2]

Other departments on campus could also be brought into the course design process. Various departments could contribute assignments that cover their area of study. For example, the Nursing department could contribute a 
spreadsheet assignment entering and charting blood glucose results. The business department could contribute a financial spreadsheet assignment. The CIS instructor should not be afraid to seek out expertise from these content areas.

Giving the student assignments that are meaningful as well as challenging is important. Research has shown that this can be an essential part of the learning process [11]

\section{CONCLUSION}

"There is clear and widespread agreement among the public and educators that all students need to be proficient computer users or "computer literate." However, there seems to be only a vague notion of what computer literacy really means." [5] Technology is everywhere and computers are in every phase of our lives, therefore it is necessary for everyone to be computer literate. [4]

The debate of what should be taught in an introductory CIS course will continue for many years to come. Engaging all who have a vested interest in the Computer Literacy course will increase the success of the course. It also may mean that the course will remain within the CIS department. Previous research has also indicated that surveying the students as to their perceived importance of topics in an introductory computer course might be another successful approach [9]. But one could argue that students do know what they need to know!

\section{REFERENCES}

1. Ausubel, D.P., and F.G. Robinson. School Learning: An Introduction to Educational Psychology. New York. Holt, Rienhart and Winston, 1969.

2. Baugh J. 2007, The Disconnect of the Non-Computer Information Systems Major to the Information Systems Literacy Course. Information Systems Education Journal, 5 (18). http://isedj.org/5/18/. ISSN: 1545-679X. (Also appears in The Proceedings of ISECON 2006: §2123. ISSN: 1542-7382.)

3. Ching, C.; Basham, J.; Jang, E., 2005, “The Legacy of the Digital Divide” Urban Education v40 n4 p394-411 Jul 2005

4. Creighton Walter, Kilcoyne Margaret, Tarver Rick, \& Wright Sarah.(2006). Computer Literacy Levels of Students Enrolling in a Post-secondary computer applications/information technology course. Information Technology, Learning, and Performance Journal, 24(1), 15-23. Retrieved May 13, 2011, from ABI/INFORM Global. (Document ID: 1292112771).

5. Eisenberg Michael B. and Johnson Doug http://www.libraryinstruction.com/info-tech.html

6. Filsell, J. and Barnes, A. 2002, Researching pedagogy and teaching methodologies that transform student learning in South Australian classrooms. In Proceedings of the Seventh World Conference on Computers in Education Conference on Computers in Education: Australian Topics - Volume 8 (Copenhagen, Denmark, July 29 - August 03, 2001). A. McDougall, J. Murnane, and D. Chambers, Eds. ACM International Conference Proceeding Series, vol. 26. Australian Computer Society, Darlinghurst, Australia, 23-30.

7. Hamilton, N., (2007) "Faculty Autonomy and Obligation”, Academe, v93 n1 p36-42 Jan-Feb. 7 pp.

8. IS2010, Model Curriculum and Guidelines http--www.acm.org-education-curriculaIS\%202010\%20ACM\%20final.pdf

9. Kim,Chung, Peterson, Dane (1992) "The introductory computer course: Business majors' perceived importance of topics.” Journal of Education for Business; Jul/Aug92, Vol. 67 Issue 6, p361, 5p, 5 Charts

10. Mackin, Johnson, and Paranto 2006, Redesign of Introduction to Computers Course. Information Systems Education Journal, 4 (8). http://isedj.org/4/8/. ISSN: 1545-679X. (Also appears in The Proceedings of ISECON 2004: §3432. ISSN: 1542-7382.)

11. Martin, J., Hands, K., Lancaster, S., Trytten, D., and Murphy, T. 2008, Hard But Not Too Hard: Challenging Courses and Engineering Students. College Teaching; Spring2008, Vol. 56 Issue 2, p107-113, 7p, 1 chart, 4 graphs

12. Mason, J.;McMorrow, R., 2006, "YACLD: yet another computer literacy definition”, Journal of Computing Sciences in Colleges Volume 21 , Issue 5 (May 2006) Pages: 94-100 
Volume XII, No. 2, pp 100-108, 2011

13. Ormerod, Dana E. "Computers across the Curriculum: Teaching a Computer Literacy Course for MultiDisciplinary Use in a Network Environment--Content and Pedagogy" Association of Small Computer Users in Education (ASCUE) Summer Conference. Proceedings (28th, North Myrtle Beach, South Carolina, June 18-22, 1995); see IR 017305.

14. Pettinger, R.. (2007, December). The role of computer literacy in skills pinch. Computer Weekly,16. Retrieved May 13, 2011, from ProQuest Computing. (Document ID: 1414471401).

15. Taylor Estelle, Goede Roelien, Steyn Tjaart, (2011) "Reshaping computer literacy teaching in higher education: Identification of critical success factors", Interactive Technology and Smart Education, Vol. 8 Iss: 1, pp.28 - 38

16. VanLengen and Haney 2006, Fundamentals of Information Systems Alternatives. Information Systems Education Journal, 4 (30). http://isedj.org/4/30/. ISSN: 1545-679X. (Also appears in The Proceedings of ISECON 2005: §4112. ISSN: 1542-7382.) 
Volume XII, No. 2, pp 100-108, 2011

\section{APPENDIX}

Figure 1 - Summary of CIS Intro Course Topics By School

\begin{tabular}{|l|c|c|c|c|c|c|c|}
\hline \multicolumn{1}{|c|}{ School } & Spreadsheet & Database & Web & Concepts & Business & Networking & Programming \\
\hline Univ of Pitt & $\mathrm{X}$ & $\mathrm{X}$ & $\mathrm{X}$ & $\mathrm{X}$ & $\mathrm{X}$ & $\mathrm{X}$ & $\mathrm{X}$ \\
\hline Duquesne & & $\mathrm{X}$ & & $\mathrm{X}$ & $\mathrm{X}$ & & \\
\hline Indiana Univ of PA & & $\mathrm{X}$ & $\mathrm{X}$ & $\mathrm{X}$ & $\mathrm{X}$ & & \\
\hline California Univ of PA & $\mathrm{X}$ & & & $\mathrm{X}$ & $\mathrm{X}$ & & \\
\hline Seton Hill Univ & $\mathrm{X}$ & $\mathrm{X}$ & $\mathrm{X}$ & $\mathrm{X}$ & $\mathrm{X}$ & $\mathrm{X}$ & \\
\hline Point Park & $\mathrm{X}$ & $\mathrm{X}$ & & & $\mathrm{X}$ & & \\
\hline Grove City & $\mathrm{X}$ & $\mathrm{X}$ & $\mathrm{X}$ & $\mathrm{X}$ & $\mathrm{X}$ & & \\
\hline West Virgina Univ & $\mathrm{X}$ & $\mathrm{X}$ & $\mathrm{X}$ & & $\mathrm{X}$ & & \\
\hline St Vincents & $\mathrm{X}$ & $\mathrm{X}$ & $\mathrm{X}$ & $\mathrm{X}$ & $\mathrm{X}$ & $\mathrm{X}$ & $\mathrm{X}$ \\
\hline Carlow & $\mathrm{X}$ & & $\mathrm{X}$ & $\mathrm{X}$ & $\mathrm{X}$ & & \\
\hline Carnegie Mellon & $\mathrm{X}$ & $\mathrm{X}$ & $\mathrm{X}$ & $\mathrm{X}$ & $\mathrm{X}$ & $\mathrm{X}$ & $\mathrm{X}$ \\
\hline Washington and Jefferson & $\mathrm{X}$ & & $\mathrm{X}$ & $\mathrm{X}$ & $\mathrm{X}$ & & \\
\hline Waynesburg & $\mathrm{X}$ & & $\mathrm{X}$ & $\mathrm{X}$ & $\mathrm{X}$ & & \\
\hline Gannon & $\mathrm{X}$ & $\mathrm{X}$ & $\mathrm{X}$ & $\mathrm{X}$ & $\mathrm{X}$ & $\mathrm{X}$ & \\
\hline Penn State & $\mathrm{X}$ & $\mathrm{X}$ & $\mathrm{X}$ & $\mathrm{X}$ & $\mathrm{X}$ & & \\
\hline Robert Morris Univ & $\mathrm{X}$ & $\mathrm{X}$ & $\mathrm{X}$ & $\mathrm{X}$ & $\mathrm{X}$ & $\mathrm{X}$ & \\
\hline
\end{tabular}

Figure 2. - Summary of Topics Taught in CIS Intro Course

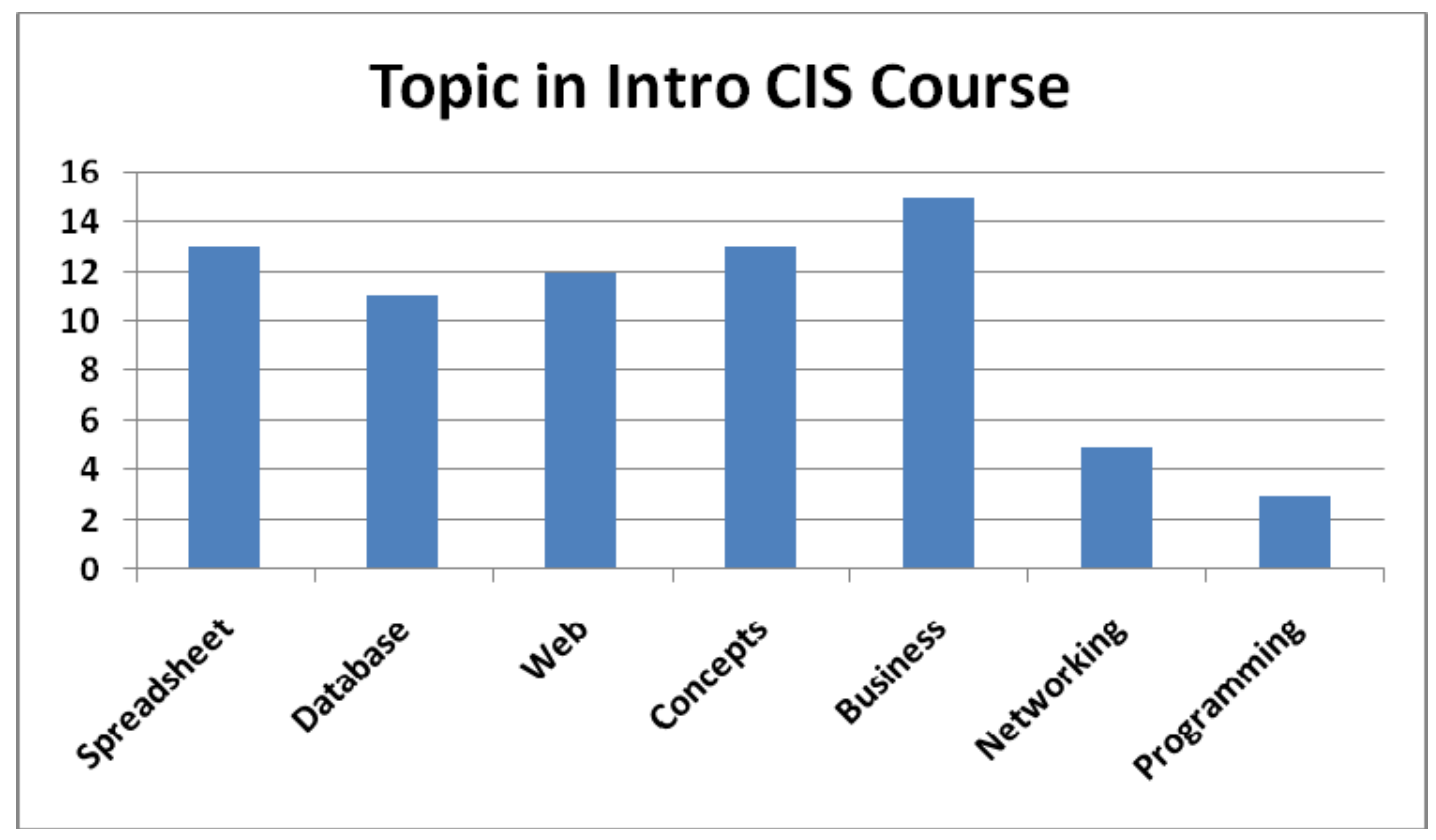

